\title{
FEATURES OF APPLICATION OF TIMBER HARVEST METHODS IN THE FORESTS OF UKRAINE
}

\author{
O. V. TOKARIEVA, PhD, Assistant Professor \\ https://orcid.org/0000-0002-1617-7025, e-mail: o.v.tokareva@nubip.edu.ua \\ National University of Life and Environmental Sciences of Ukraine
}

In this paper, we present the basic features of final felling in Ukraine. Prevailing timber harvest methods and their areas were considered. For analyzing the volumes of modern forest exploitation were data from permits for final felling on actual cuttings in of all forestry enterprises of Ukraine. Studies were conducted for the period 2019-2020. It was installed that clearcutting is the main timber harvest method (95\% in Kyiv region, $45 \%$ in Lviv region). Among other methods, the leading place is shelterwood. During the study period, only two (uniform and strip) and three (group) reception of shelterwood were recorded. The areas of stands designed for shelterwood final felling are significantly lower than those defined by the rules. The use of the single tree selection method is more related to deciduous plantations, which indirectly indicates the predominance of deciduous stands of uneven-aged stands in Ukraine.

Shelterwood and single tree selection removes methods are applied in Chernihiv, Chernivtsi, Ivano-Frankivsk, Kyiv, Lviv, Zakarpattia, Zhytomyr regions. A characteristic feature is the predominance of coniferous areas stands during clearcutting. Area of deciduous stands are larger compared to coniferous during shelterwood. Combined method is the less popular in Ukraine. It has been carried out at 9,4 hectares for two years.

Average logging areas range from 1-2 hectares for clearcutting, 1-5 hectares for shelterwood and 2-8 hectares for combined method. Designed logging areas are significantly lower than those introduced by Ukrainian legislation.

The implementation of the principles of close-to-nature forestry can be provided by reduction in the volume of clearcutting. Increasing of shelterwood and single tree selection methods, which are close-to-nature, will ensure the cultivation of mixed uneven-aged forest stands of high vigor, productivity and biological stability.

Studies reflect regional and species features and benefits of timber harvest methods in the forests of Ukraine.

Keywords: clearcutting, single tree selection removes, shelterwood and combined methods, even-aged and uneven-aged stand.

Introduction. Forests are complex ecosystems that must be treated carefully and skillfully. The present is demanding a higher level of resource stewardship to conserve and protect a wide array of forest-related values. The total area of forest lands in Ukraine is 10.4 million hectares, forests covered area is 9.6 million ha or 15.9 per cent of the Ukraine's territory. Approximately half of forest land areas are production forest, with the remainder in reserves and non-production forest areas. More than $16,1 \%$ of the total area of forest in Ukraine is held in reserves for conservation. The majority of the area available for wood production is artificial forest. By reserves of industrial stem wood, Ukraine ranks the sixth in Europe. In Ukraine, forest stands dominated by finewood occupy $88,6 \%$ of wood covered area. Of them, pine accounts for $33,6 \%$ (Pinus silvestris L. leading the way), oak - 24,4\% (Quercus robur L. dominates), and beech (Fagus silvatika L.) $-7,4 \%$ (Timber industry, 2007).

For each forest enterprise the allowable cut is calculated annually, based on forest inventory data and distinguished 
by tree species groups. The real size of harvest felling usually equals $84-90 \%$ of the allowable volume of cutting. Special use of forest resources at the allocated forest plot shall be carried out on the basis of a special permit (The Forest Code, 2006). Annually in Ukraine there harvested about 20 million $\mathrm{m}^{3}$ of wood. About $45 \%$ of wood is harvested in main cuttings, $70 \%$ of this wood is round.

Recent government measures include a pilot project of an electronic register of logging tickets for timber harvesting (State Forest, 2020).

Analysis of recent researches and publications. Ecologically oriented forestry advocates for mixed (multiple-species) and structurally complex forests. This forestry is directed toward a diverse array of objectives (ecosystem function, biodiversity conservation, wildlife habitats, visual quality, nutrient recycling, water retention, soil productivity, carbon sequestration, and amenity values), in addition to the provision of classic economic forestry commodities (Yavorovskyi et al., 2019). Close-to-nature forestry is the system of forest management that promote a continuous renewal and formation of stands which most similar in structure and genesis to natural ones (Krynytskyi, 2017). Research of cutting methods and volumes of timber harvesting were carry out in mountain forests in Ukrainian Carpathians (Parpan et al., 2017). The effect of technological processes and systems of machines used in mountain forests on the forest environment were estimated by Byblyuk et al., 2010. The logging methods in Eastern European Countries, including Ukraine were studied by Moskalik et al., 2017.

Analyze of timber harvest methods on the entire territory of Ukraine were not conducted.

Purpose of the research. The aim of this study was to reveal the current vol- umes of forest use in Ukraine; to establish the prevailing methods of timber harvesting; to determine the average areas, in particular limited (by area) cutting; to identify the dependence of the use of non-clearcutting in coniferous and deciduous stands.

Materials and methods of the research. Materials for analyzing the volumes of modern forest exploitation were data from the open register of permits for timber harvesting in of all forestry enterprises of Ukraine (Forest tickets). Studies were conducted for the period 20192020. In order to achieve the intended aim, we analyzed a large amount of data, among others, the characteristics of forest resources, methods of timber harvesting, their area, differentiation in terms of species. Particular attention was paid to the use of discontinuous felling methods within the regions of Ukraine.

Results of the research and their discussion. In Ukraine forest growing relies on three parts of a silvicultural system: regeneration, stand tending and harvesting.

Regeneration method is a cutting procedure by which a new age class is created. The major regeneration methods are clearcutting, shelterwood, single tree selection and combined. Choosing of regeneration methods is carried out depending on the natural and economic conditions, location, the functioning role and species composition of the forests, type of regeneration (natural, artificial, coppice). To better understanding what regeneration methods is necessary to apply, we should to analyze the following parameters: the main function of forest, species composition, origin and structure of the stand.

Forests with ecological (protective) and social functions can be make a project at non-clearcuting methods. Carrying out of clearcuting in reserves is prohibited.

For growth even-aged (two-aged) forest it can be applied clearcuting and shelterwood methods. 
Clearcuting (in Ukraine includes seed tree cutting) is a regeneration or harvest method that removes essentially all trees in a stand (Matthews, 1992).

Clearcuting method includes four stages of even-aged regeneration formation: mature stand $\rightarrow$ clearcut $\rightarrow$ establishment $\rightarrow$ tending $\rightarrow$ mature stand. It can be highly profitable. However, its application in ecological or social functions forests often involves unacceptable risks and impairs landscape values.

This method can be employed during coppice versus clearcutting.

Seed tree cutting is the removing of all trees except for a small number of trees retained for seed production and to produce a new age class in a fully exposed microenvironment. Seed tree method includes five stages of even-aged regeneration formation: mature stand $\rightarrow$ seed tree cut $\rightarrow$ establishment $\rightarrow$ removal cut $\rightarrow$ tending $\rightarrow$ mature stand.

The maximum area of clearcuting (seed tree cutting) in production forests can be up to 5 hectares (only for deciduous trees), and in forests that are not used for timber production -3 hectares (for deciduous and coniferous trees).

There are only clearcuting is used in Cherkasy, Dnipropetrovsk, Donetsk, Kharkiv, Kherson, Khmelnytsk, Kirovohrad, Luhansk, Mykolaiv, Odesa, Poltava, Rivne, Sumy, Volyn, Zaporizhzhia region.

Shelterwood is the cutting of most trees, leaving those needed to produce sufficient shade to produce a new age class in a moderated microenvironment. Shelterwood method includes five stages of even-aged regeneration formation.

Shelterwood has the next stages: mature stand $\rightarrow$ establishment cut $\rightarrow$ establishment $\rightarrow$ no removal cut $\rightarrow$ tending $\rightarrow$ mature stand.

Shelterwood method includes the various ways of successive regeneration felling together with the selection system. Old crop is felled over the area in uni- form, group or strip. The number of receptions of uniform and strip shelterwood can be 2 or 3 . The duration of this method is up to 20 years.

The maximum area of shelterwood in production forests can be up to 10 hectares, and in forests that are not used for timber production -5 hectares.

Another type of harvesting is group shelterwood. It is logging cuts too small to be considered clearcut. The number of receptions of group shelterwood can be 3 or 4 .

The maximum area of group shelterwood can be up to $300 \mathrm{~m}^{2}$. The number of raincoats for felling is $4-8$ pieces. The duration of these felling is $30-40$ years. This cutting contributes to light demanding species growing faster.

Uniform, group, strip shelterwood method are intensively applied Chernihiv, Chernivtsi, Ivano-Frankivsk, Kyiv, Lviv, Ternopil, Vinnytsia, Zakarpattia, Zhytomyr region. For the last 2 years uniform and strip shelterwood were carried out in two receptions, and group shelterwood - in three.

The last reception of shelterwood is carried out in the presence of viable natural regeneration from seed in quantity: not less than 8 thousand pieces in pine forests; not less than 15 thousand pieces in beech and fir forests; not less than 12 thousand pieces in spruce forests; not less than 10 thousand pieces in oak, maple, ash and other forests. Figure 5 shows the area allocated for the first reception of uniform felling in a deciduous stand.

Single tree selection removes individual trees of all size classes more or less uniformly throughout the stand to maintain an uneven-aged stand and achieve other stand structural objectives. Single tree selection method is an uneven-aged method where individual trees are removed uniformly throughout the stand, to increase growth of remaining trees and to provide space for regeneration. The basic tenets for successful single tree selection are to provide sufficient 


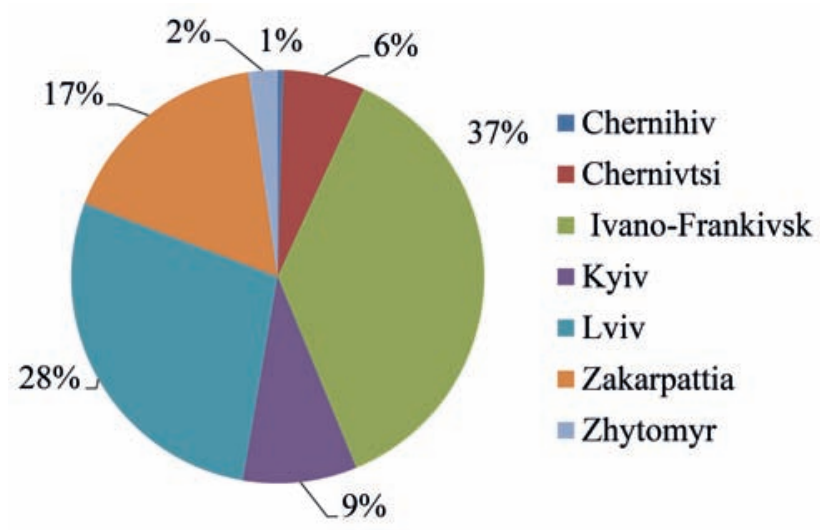

Fig. 1. Distribution of the stand area intended for single tree selection method by regions of Ukraine

gaps for regeneration and to maintain vigor throughout the stand.

This method can be strong (removal cut 25-35\%), medium (11-24\%) and low (up to $10 \%$ ) intensity. If is carried out strong cutting intensity, the frequency should be more than 20 years; medium intensity - 11-20 years and low intensity - up to 10 years.

In the last 2 years, the single tree selection method was used in Chernihiv (4,5 hectares), Chernivtsi (62 hectares), Ivano-Frankivsk (358 hectares), Kyiv (86 hectares), Lviv (272 hectares), Zakarpattia (164 hectares), Zhytomyr (22 hectares) region (figure 1). The largest areas of single tree selection method are carried out in Broshniv, Deliatyn, Sambir, Drohobych, Skole, IvanoFrankivsk, Teteriv, Kolomyia, Rava-Ruska State Forestry Enterprise; Berehomet, Brustury State Forestry-Hunting Enterprise; Oster, Uzhhorod State Military Forestry Enterprise.

While single tree selection is been carried out, timber harvest is time consuming, but is the best way for continuous cover forestry.

The distribution of areas of stands assigned to the single tree selection method by tree species allows assessing forestry benefits separately for coniferous and deciduous stands (figure 2).

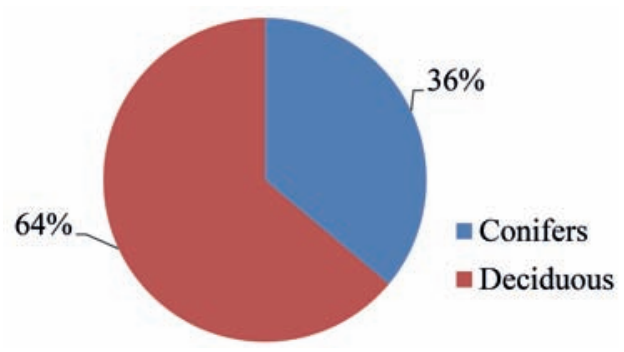

Fig. 2. Distribution of the stand areas intended for single tree selection method by tree species

As for the single tree selection method, it is most often used in deciduous stands $(64 \%)$. Usually in Ukraine deciduous stands are uneven-aged and complex in structure. In coniferous stands, this method is used to transform evenaged in uneven-aged stands.

Having selected the regions of Ukraine in which non-continuous methods are introduced to the greatest (Lviv) and least (Kyiv) extent, we obtained the following results (fig. 3 and fig. 4).

There are only $5 \%$ of area, where was carried out non-clearcutting methods in Kyiv region. In $95 \%$ of area was conducted not close-to-nature cutting. Kyiv 
region has a lot of recreational forest, in which better to provide ecologically oriented forestry, in particular single tree selection removes.

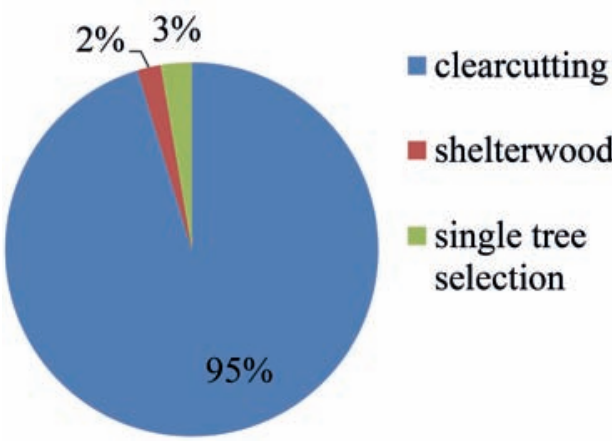

Fig. 3. Distribution of used harvesting methods in Kyiv region

There are the same area with clearcutting and shelterwood in Lviv region more than 2000 hectares each. Single tree selection removes amount 270 hectares. So much more than half of the area is restored by close-to-nature forestry.

In Ukraine there is a combined timber harvest method. This method is a hybrid with the single tree selection and shelterwood methods. The maximum area of combined method is up to 5 hectares. Combined method was carried out only in Novoaidar State Forestry-Hunting Enterprise $(4,4$ hectares), Teteriv State Forestry Enterprise (5,0 hectares). The last one was carried out in coniferous stands located in the recreational area (figure 6).

As can be seen from table 1, the areas of stands designed for final felling are significantly lower than those defined by the rules (Rules, 2009).

A characteristic feature of clearcutting is the predominance of areas in coniferous stands compared to deciduous. For example, in Ivano-Frankivsk region aver-

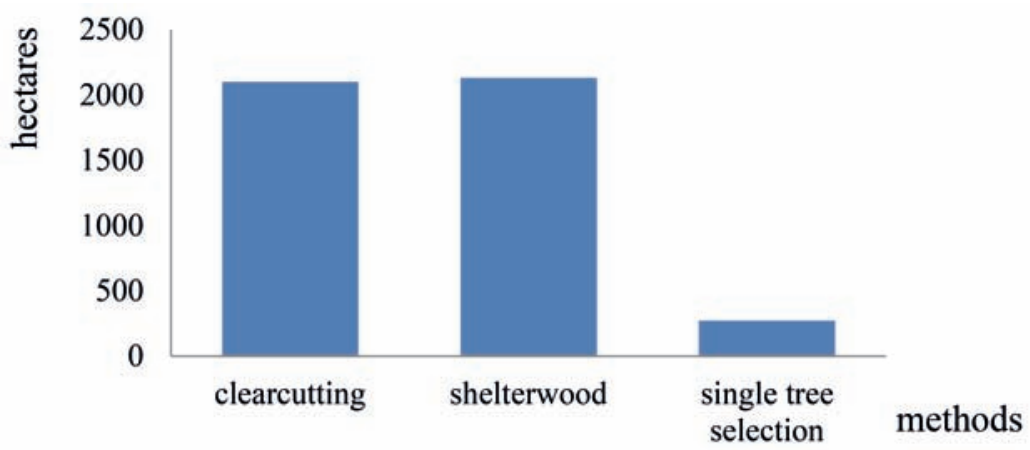

Fig. 4. Area of harvesting methods in Lviv region

1. Average logging area, hectares

\begin{tabular}{|l|c|c|c|c|c|c|}
\hline \multirow{2}{*}{ Regions } & \multicolumn{2}{|c|}{ Clearcutting } & \multicolumn{2}{c|}{ Shelterwood } & \multicolumn{2}{c|}{ Single tree selection } \\
\cline { 2 - 7 } & Conifers & Deciduous & Conifers & Deciduous & Conifers & Deciduous \\
\hline Chernihiv & 2,12 & 1,85 & 5,25 & 4,08 & 4,50 & - \\
\hline Chernivtsi & 1,49 & 1,32 & 1,80 & 2,07 & 7,75 & - \\
\hline Ivano-Frankivsk & 1,84 & 1,34 & 1,04 & 1.10 & 3,00 & 3,58 \\
\hline Kyiv & 1,79 & 1,77 & 3,76 & - & 3,15 & 2,53 \\
\hline Lviv & 0,98 & 0,87 & 0,84 & 1,00 & 1,90 & 2,58 \\
\hline Zakarpattia & 1,19 & 0,9 & - & 1,00 & 4,17 & 4,59 \\
\hline Zhytomyr & 1,80 & 1,76 & 2,46 & - & 2,7 & 3,25 \\
\hline
\end{tabular}




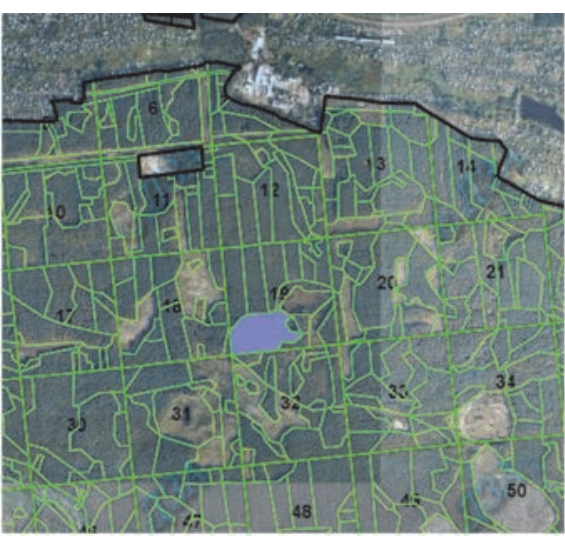

Fig. 5. Shelterwood method area in Ivano-Frankivsk Forestry Enterprise

age logging area of clearcutting are 1,84 hectares of conifers and 1,34 hectares of deciduous stands. Shelterwood has the opposite feature. In all regions, except Chernihiv, the average area allocated for this timber harvest method in deciduous stands are larger compared to coniferous.

Single tree selection method has no restrictions on the area. Therefore, the maximum area of this method was up to 10 hectares.

The main method of cleaning loggers consists in collecting felling residues in heaps for decay. Less often it uses the fire method of cleaning areas from felling residues or combined (fire and non-fire methods).

Conclusions and future perspectives. Forest in Ukraine usually composed of one or very few tree species. To achieve an irregular structure, these stands must be transformed through by measures. These measures must consider current and future stand stability, the development of uneven-aged structure, promotion of natural regeneration and sustained timber production.

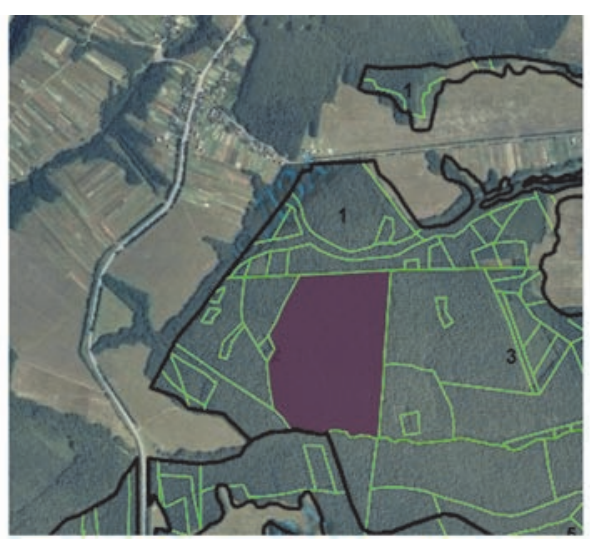

Fig. 6. Combined method area in Teteriv Forestry Enterprise

As we have seen, clearcutting remains the main method in Ukraine. The most foresters choose clearcutting because it's an efficient way to harvest timber and create an ideal site for growing the next generation trees. Shelterwood and single tree selection methods were used in Chernihiv, Chernivtsi, Ivano-Frankivsk, Kyiv, Lviv, Zakarpattia, Zhytomyr region.

The rich natural conditions of Ukraine allow the use of non-clearcutting methods on a much larger scale. The experience of such felling is insignificant in the eastern and southern regions of Ukraine. Usually shelterwood and single tree selection methods are time consuming, but they are the best way for continuous cover forestry.

Recently, methods of timber harvesting are moving away from clearcutting to selective cutting. The implementation of the principles of close-to-nature forestry can be provided by reduction in the volume of clearcutting. Increasing of shelterwood and single tree selection methods, which are close-to-nature, will ensure the cultivation of mixed uneven-aged forest stands of high vigor, productivity and biological stability.

\section{References}

Byblyuk, N., Styranivsky, O., Korzhov, V., \& Kudra, V. (2010). Timber harvesting in the Ukrainian Carpathians: Ecological prob- lems and methods to solve them. Journal of Forest Science, 56 (7), 333-340. https:// www.researchgate.net/publication/ 
298115486 Timber harvesting in the Ukrainian_Carpathians_Ecological_problems_and_methods_to_solve_them.

Forest tickets. Available at https://lk.ukrforest. com/forest-tickets.

Krynytskyi, H. T., Chernyavskyi, M. V., Krynytska, O. H., Deineka, A. M., Kolisnyk B. I., \& Tselen, Ya. P. (2017). Close-toNature Forestry as the Basis for Sustainable Forest Management in Ukraine. Scientific Bulletin of UNFU, 27 (8), 26-31. https://doi. org/10.15421/40270803.

Matthews, John D. (1992). Silvicultural systems. Oxford: Clarendon press.

Moskalik, T., Borz, S., Dvořák, Ji., Ferencik, M., Glushkov, S., Muiste, P., Lazdiņš, A., \& Styranivsky, O. (2017). Timber Harvesting Methods in Eastern European Countries: a Review. Croatian Journal of Forest Engineering: Journal for Theory and Application of Forestry Engineering, 38 (2), 231-241. Available at https://www.researchgate.net/ publication/319902722Timber_Harvesting_ Methods_in_Eastern_European_ Countries a Review.

Parpan, V., Hūdyma, V. D., \& Parpan, T. (2017). Cutting methods and volumes of timber har- vesting in mountain forests in Ukrainian Carpathians. Forestry and agroforestry, 131, 135-142 [in Ukrainian].

Procedure of Forest Division into Categories and the Allocation of Specially Protected Forest Sites. (2007). Available at https://zakon.rada.gov.ua /laws/show/733-2007$\% \mathrm{D} 0 \% \mathrm{BF}$ Text.

Rules of final felling. (2009). Available at https:// zakon.rada.gov.ua/laws/show/z008510\#Text.

State Forest Resources Agency of Ukraine. (2020). The State Agency of Forest Resources of Ukraine is launching a pilot project of an electronic register of logging tickets for timber harvesting. Available at http:// dklg.kmu.gov.ua/forest /control/uk/index.

The Forest Code. (1994). Available at https://zakon.rada.gov.ua/laws/show/3852-12\#Text.

Timber industry of Ukraine. (2007). Ministry of Economic Development and Trade. Available at http://www.ukrexport.gov.ua/eng/ economy/brief/industry /ukr/196.html.

Yavorovskyi, P. P., Maurer, V. M., Zibtsev, S. V., Maliuha, V. M., Kaidyk, O. Yu., \& Sendonin, S. Ye. (2019). Ecologically oriented forestry. Kyiv: Naukova stolytsia [in Ukrainian].

\section{Токарева О. В. \\ ОСОБЛИВОСТІ ЗАСТОСУВАННЯ СИСТЕМ РУБОК ГОЛОВНОГО КОРИСТУВАННЯ В ЛІСАХ УКРАЇНИ}

У роботі проаналізовано особливості проведення рубок головного користування в Україні. Розглянуто переважні системи рубок головного користування та їх площі. Для аналізу обсягів сучасного лісокористування було використано реєстр лісорубних квитків для всіх лісогосподарських підприємств України. Дослідження проведено за період 2019-2020 рр. Було встановлено, що суцільно лісосічна рубка є основною системою під час проведення рубок головного користування та становить 95 \% у Київській області, 45 \% у Львівській області. Серед несуцільних способів рубок перше місце посідає рівномірно-поступова рубка. Протягом досліджуваного періоду було зафріксовано проведення лише двоприйомних (рівномірно-поступових та смугово-поступових) і триприйомних (групово-поступових) рубки. Причому суцільно-лісосічні рубки найчастіше проводять у хвойних деревостанах, а поступові - у листяних.

Використання вибіркової системи рубок здебільшого стосується листяних насаджень, що опосередковано свідчить про переважання різновікових листяних деревостанів в Україні. Добровільно-вибіркові рубки проводили у Чернігівській, Чернівецькій, Івано-Франківській, Київській, Львівській, Закарпатській, Житомирській областях. Комбіновану систему рідко застосовують в Україні. Протягом останніх двох років ії провели на площі 9,4 га.

Середні площі рубок головного користування коливаються від 1-2 гектарів під час суцільних рубок, 1-5 гектарів під час поступових рубок та 2-8 гектарів при застосуванні комбінованої системи. Запроектовані площі рубок головного користування значно нижчі від тих, що запроваджені українським законодавством.

Реалізацію принципів наближеного до природи лісівництва може бути забезпечено шляхом зменшення обсягів суцільних рубок. Збільшення площ поступової, вибіркової та комбінованої системи, які є більш наближеними до природи, забезпечать вирощування мішаних різновікових деревостанів із високою життєздатністю, продуктивністю та біологічною стійкістю. Дослідження відображають регіональні та видові особливості й переваги методів рубок головного користування.

Ключові слова: суцільна, поступова, вибіркова та комбінована системи, одновіковий різновіковий деревостани. 